\title{
Comparison on the Performance of Moringa and Neem Root Extracts on Crude Oil Degradation in Soils Environment
}

\author{
Ukpaka CP* \\ Department of Chemical/Petrochemical Engineering, Rivers State University Port Harcourt, \\ Nigeria
}

*Corresponding author: Chukwuemeka Peter Ukpaka, Department of Chemical/ Petrochemical Engineering, Rivers State University Port Harcourt, Nigeria, Email: chukwuemeka24@yahoo.com

\section{Research Article \\ Volume 4 Issue 4}

Received Date: June 29, 2020

Published Date: July 13, 2020

DOI: $10.23880 /$ ppej-16000229

\section{Abstract}

Degradation of Crude oil in different soils environment was monitored using two different species of plant extract namely moringa and Neem roots. Four different types of soil was investigation namely loamy, sandy, clay and silt soil all obtained from Niger Delta area of Nigeria as well as the Moringa and Neem roots including the alcohol and water media with the aims to extract the useful nutrient that can enhance microbial activities on crude oil degradation. The mass of $500 \mathrm{~g}$ and $600 \mathrm{~g}$ of the moringa and Neem roots fermented extracts were introduced into the various polluted soil types investigated and the result obtained show increase in degradation of Total Petroleum Hydrocarbon (TPH) with increase in time in all the soil types. Degradation of the TPH was more rapid in sandy soil environment and less in silt soil environment in moringa in water and alcohol as well as in Neem in alcohol and water media. The research work also revealed that degradation was faster in moringa in water than all others, showing the acceptability of moringa root as a major radiant for crude oil polluted environment. The aim of this research work is to examine the effectiveness of fermented moringa and Neem roots extract for remediation of crude oil polluted soils of different environment.

Keywords: Comparison; Performance; Moringa; Neem; Roots extract; Crude oil; Soil environment

\section{Introduction}

The usefulness of moringa and Neem roots extract in bioremediation of crude oil in soil environment has been studied by Ukpaka, [1]. The result obtained in the study reveals that both Moringa roots and Neem root extract are found useful in remediation of crude oil polluted soil environment, due to the present of nutrients that are utilizers by microbes present in the root extracts as well as the soil component and crude oil.

Research conducted by various groups on bioremediation of crude oil using plant extract has been reported and the usefulness of a polluted site well documented [1-5]. In bioremediation programme the first step is to determine the site and the extent of pollution. This is followed by site characterization and the site characterization is scientific intensive and a proper research work is required for a good design [6-8]. Investigation carried out reveals that for a good bioremediation programme to be achieved it requires a good engineering design which includes site inspection, bioremediation option, design concept, pilot plant, final design and site characterization [9-12]. The action of microbes in bioremediation programme are quite similar in behavior if the environmental favours their actions but in most cases, when the environmental factors is a contributing factors, the action of the microbes may defer because they found themselves in an unfavorable environment which influence their active site and several research conducted on various literature on plant materials for crude oil remediation in both soil and water environment were obtained as shown in the reference [13-20]. In most cases, the nutrient to feed on is available but the active site of the microbes is totally inhibited [21-25]. 


\section{Petroleum \& Petrochemical Engineering Journal}

The aim of this research work is to examine the most effective roots extract based to give the optimum remediation process. The results obtained in this study reveal the significance of moringa and Neem root extract in alcohol and water base solvent in enhancing bioremediation of crude oil pollution soil types of Niger Delta area of Nigeria.

\section{Material and Methods}

\section{Materials}

The following materials were used in the course of the experiment: Crude oil, soils, plastic vessels (reactors), Moringa and Neem roots, digital weighing balance, stirrer, shovel, sieve, sack bags, measuring cylinders, beakers, conical flask, Kjeldahl flask, pipette, oven, crucible, desiccators, thermometer, $\mathrm{pH}$ meter, Gas Chromatography, distilled water, sodium hexa-phosphate(II) $\left(\mathrm{NaPO}_{3}\right)_{2}$ and $_{2} \mathrm{SO}_{4}$.

\section{Sample Collection}

The soils used in this study include loamy, sandy, silt and clay soils. The soils were collected from Kpea Community, Khana Local Government Area of Rivers State. Kpea is one of the communities in Ogoni Ethnic Group in Rivers State. The soils were collected with aid of shovel and then, bagged in sack bags. Thereafter, they were transported to the Department of Chemical/Petrochemical Laboratory, Rivers State University, Port Harcourt for laboratory analysis. The Moring and Neem roots were collected from the same Wiiyaakara Community in the Khana Local Government Area of Rivers State. They were washed with distilled water to remove debris and then sundried before extraction. Water for extraction was collected from the Laboratory, while alcohol was obtained from local distillery in Bangha Community in Khana Local Government Area of Rivers State, with 97-98 \% v/v. This concentration was determined in the laboratory.

\section{Experimental Procedure}

The roots of Moringa and Neem plants were separately soaked in water and alcohol for two weeks to effectively obtain extracts from the roots. The soil samples were weighed into $500 \mathrm{~g}$ and $600 \mathrm{~g}$ separately. Each of the soil: sandy, silt, loamy and clay soils were divided into four (4) samples. Two (2) of the samples weighing $500 \mathrm{~g}$ were measured into vessels prepared to receive roots extract obtained with water and alcohol respectively. This was also done for the other two samples weighing $600 \mathrm{~g}$. Upon preparation of the soil samples, they were then contaminated with $50 \mathrm{ml}$ of crude oil and mixed properly with the aid of a stirrer, to ensure consistency of the concentration of crude oil in the soil. After stirring for about two minutes, the polluted soil samples were left undisturbed for three days. This was to allow stabilization or settlement of the soils [1]. At the third day, 100mg of the liquid extract obtained with alcohol and water as solvent, were weighed into the samples as designed. Similarly, each of the soils sample was prepared as above, but without the root extracts, which were used as control samples. Every seven (7) day, representative sample of each soil was collected for laboratory analysis to determine the physicochemical parameters, Total Petroleum Hydrocarbon (TPH) content and Total Bacteria count for 42 days (6 weeks).

\section{Sample Test Analysis}

Sample analysis of each soil was carried out in the laboratory, and the following parameters determined: $\mathrm{pH}$, electrical conductivity, moisture content, total organic carbon, Total Petroleum Hydrocarbon (TPH) content and Total Bacteria Count (TBC). The soil textural class was also determined. Also, the physiochemical properties of Moringa and Neem roots were analyzed.

\section{Results and Discussion}

\section{Analysis of Treatments and Soil Physicochemical Properties}

The physicochemical properties of moringa-water, neem-alcohol, neem-water and neem-alcohol solutions were determined as compared to those of fresh alcohol and water. These are shown in Tables $1 \& 2$. Also, as a way of determining the extent of variability of soils due to the effect of crude oil pollutant and treatment application, the physicochemical properties before and after the pollution of the soils and also, after treatment application were determined.

\begin{tabular}{|c|c|c|c|}
\hline Parameters & Fresh Alcohol & Moringa-Alcohol Extract & Neem-Alcohol Extract \\
\hline Refractive Index & 1.3493 & 1.3453 & 1.3463 \\
\hline Boiling Point $\left({ }^{\circ} \mathrm{C}\right)$ & 79.2 & 83.9 & 86.5 \\
\hline Viscosity (cst) & 3.2 & 2.46 & 2.3065 \\
\hline Density (g/cm3) & 0.9343 & 0.9498 & 0.9466 \\
\hline Colour & Clourless & Clourless & Clourless \\
\hline
\end{tabular}

Table 1: Physical Properties of Treatments Extract in Alcohol beforeApplication. 


\section{Petroleum \& Petrochemical Engineering Journal}

As shown in Table 1, the values of refractive index and colour of moringa-alcohol and neem-alcohol are negligible compared to the values for fresh alcohol. Nevertheless, after soaking moringa and neem roots in the fresh alcohol, the boiling point and density of the solutions were slightly increased, while viscosity is reduced below that of alcohol.

\begin{tabular}{|c|c|c|c|}
\hline Parameters & Water & Moringa-Water Extract & Neem-Water Extract \\
\hline $\mathrm{pH}$ & 6.39 & 6.18 & 6.25 \\
\hline Chloride $(\mathrm{mg} / \mathrm{l})$ & 43.7 & 64.85 & 83.51 \\
\hline Sulphate $(\mathrm{mg} / \mathrm{l})$ & 6.26 & 20.63 & 20.8 \\
\hline Total hardness & 28.17 & 49.14 & 47.3 \\
\hline Iron Content (mg/l) & 0.03 & 0.281 & 0.269 \\
\hline Conductivity $(\mu \mathrm{S} / \mathrm{cm})$ & 41.04 & 1.052 & 1.665 \\
\hline TDS (mg/l) & 2.8 & 86.92 & 8.06 \\
\hline TSS (mg/l) & 2.8 & 5.98 & 8.06 \\
\hline Nitrate (mg/l) & 0.22 & 6.2 & 5.99 \\
\hline Calcium (mg/l) & 39.88 & 18.27 & 15.36 \\
\hline Salinity (mg/l) & 53.88 & 89.8 & 91.41 \\
\hline Temperature $\left({ }^{\circ} \mathrm{C}\right)$ & 29.1 & 29.5 & 29.7 \\
\hline Density (g/cm3) & 1.0007 & 1.0002 & 0.9974 \\
\hline
\end{tabular}

Table 2: Physicochemical Properties of Treatment Water Extract beforeApplication.

Table 2 showed there are changes in the properties of water after soaking moringa and neem roots into it. This implied that moringa and neem roots were responsible for the change in water property.

\begin{tabular}{|c|c|c|}
\hline Parameters & Before Pollution & After Pollution \\
\hline Density $(\mathrm{g} / \mathrm{cm} 3)$ & 1.75 & 4.8 \\
\hline E.C $(\mu \mathrm{S} / \mathrm{cm})$ & 10 & 15.6 \\
\hline $\mathrm{pH}$ & 5.85 & 5.48 \\
\hline $\mathrm{MC}(\%)$ & 9 & 30.5 \\
\hline TOC $(\%)$ & 2.64 & 4.77 \\
\hline TN $(\mathrm{mg} / \mathrm{kg})$ & 2.27 & 6.46 \\
\hline $\mathrm{TP}(\mathrm{mg} / \mathrm{kg})$ & 1.14 & 4.68 \\
\hline
\end{tabular}

Table 3: Physicochemical Properties of Loamy Soil beforeand after Pollution.

\begin{tabular}{|c|c|c|c|c|c|c|c|c|c|}
\hline Parameters & Control & MW-500 & NW-500 & MA-500 & NA-500 & MW-600 & NW-600 & MA-600 & NA-600 \\
\hline Density (g/cm3) & 3.94 & 2.39 & 2.74 & 3.22 & 3.59 & 1.97 & 2.29 & 2.93 & 3.17 \\
\hline E.C $(\mu \mathrm{S} / \mathrm{cm})$ & 14.2 & 13.53 & 13.73 & 13.67 & 13.85 & 11.72 & 12.01 & 13.6 & 13.82 \\
\hline $\mathrm{pH}$ & 5.81 & 6.92 & 6.74 & 6.63 & 6.53 & 6.98 & 6.94 & 6.67 & 6.63 \\
\hline MC (\%) & 25.01 & 15.16 & 17.39 & 20.44 & 22.81 & 12.51 & 14.55 & 18.61 & 20.13 \\
\hline TOC (\%) & 3.72 & 2.37 & 2.61 & 2.9 & 2.95 & 1.96 & 2.28 & 2.72 & 2.82 \\
\hline TN (mg/kg) & 3.36 & 1.85 & 2.07 & 2.39 & 2.89 & 1.36 & 1.79 & 2.26 & 2.71 \\
\hline TP (mg/kg) & 2.43 & 1.34 & 1.5 & 1.73 & 2.1 & 0.98 & 1.3 & 1.64 & 1.97 \\
\hline
\end{tabular}

Table 4: Physicochemical Properties of Loamy Soil after 84 Days Treatment. 
Petroleum \& Petrochemical Engineering Journal

\begin{tabular}{|c|c|c|}
\hline Parameters & Before Pollution & After Pollution \\
\hline Density $(\mathrm{g} / \mathrm{cm} 3)$ & 9.84 & 13.52 \\
\hline E.C $(\mu \mathrm{S} / \mathrm{cm})$ & 40 & 60 \\
\hline $\mathrm{pH}$ & 5.64 & 5.34 \\
\hline MC $(\%)$ & 8.5 & 30.5 \\
\hline TOC $(\%)$ & 4.71 & 4.86 \\
\hline TN $(\mathrm{mg} / \mathrm{kg})$ & 2.03 & 6.22 \\
\hline TP $(\mathrm{mg} / \mathrm{kg})$ & 1.28 & 3.74 \\
\hline
\end{tabular}

Table 5: Physicochemical Properties of Silt Soil beforeand after Pollution.

\begin{tabular}{|c|c|c|c|c|c|c|c|c|c|}
\hline Parameters & Control & MW-500 & NW-500 & MA-500 & NA-500 & MW-600 & NW-600 & MA-600 & NA-600 \\
\hline Density (g/cm3) & 11.09 & 6.72 & 7.71 & 9.06 & 10.11 & 5.54 & 6.45 & 8.25 & 8.92 \\
\hline E.C $(\mu \mathrm{S} / \mathrm{cm})$ & 54.6 & 52.02 & 52.8 & 52.56 & 53.28 & 45.06 & 46.2 & 52.32 & 53.16 \\
\hline $\mathrm{pH}$ & 5.76 & 6.86 & 6.68 & 6.58 & 6.48 & 6.92 & 6.88 & 6.61 & 6.57 \\
\hline MC (\%) & 25.01 & 15.16 & 17.39 & 20.44 & 22.81 & 12.51 & 14.55 & 18.61 & 20.13 \\
\hline TOC (\%) & 3.79 & 2.42 & 2.66 & 2.95 & 3 & 1.99 & 2.32 & 2.78 & 2.88 \\
\hline TN (mg/kg) & 3.23 & 1.79 & 1.99 & 2.3 & 2.79 & 1.31 & 1.72 & 2.18 & 2.61 \\
\hline TP (mg/kg) & 1.94 & 1.07 & 1.2 & 1.38 & 1.68 & 0.79 & 1.04 & 1.31 & 1.57 \\
\hline
\end{tabular}

Table 6: Physicochemical Properties of Silt Soil after 84 Days Treatment.

\begin{tabular}{|c|c|c|}
\hline Parameters & Before Pollution & After Pollution \\
\hline Density $(\mathrm{g} / \mathrm{cm} 3)$ & 3.17 & 5.11 \\
\hline E.C $(\mu \mathrm{S} / \mathrm{cm})$ & 20 & 29.12 \\
\hline $\mathrm{pH}$ & 5.36 & 5.27 \\
\hline $\mathrm{MC}(\%)$ & 5 & 36.4 \\
\hline TOC $(\%)$ & 4.065 & 4.665 \\
\hline $\mathrm{TN}(\mathrm{mg} / \mathrm{kg})$ & 3.88 & 7.86 \\
\hline $\mathrm{TP}(\mathrm{mg} / \mathrm{kg})$ & 2.47 & 5.68 \\
\hline
\end{tabular}

Table 7: Physicochemical Properties of Clay Soil beforeand after Pollution.

\begin{tabular}{|c|c|c|c|c|c|c|c|c|c|}
\hline Parameters & Control & MW-500 & NW-500 & MA-500 & NA-500 & MW-600 & NW-600 & MA-600 & NA-600 \\
\hline Density (g/cm3) & 4.19 & 2.54 & 2.91 & 3.42 & 3.82 & 2.1 & 2.44 & 3.12 & 3.37 \\
\hline E.C $(\mu \mathrm{S} / \mathrm{cm})$ & 26.5 & 25.25 & 25.63 & 25.51 & 25.86 & 21.87 & 22.42 & 25.39 & 25.8 \\
\hline pH & 5.75 & 6.85 & 6.68 & 6.57 & 6.47 & 6.91 & 6.88 & 6.6 & 6.56 \\
\hline MC (\%) & 29.85 & 18.09 & 20.75 & 24.39 & 27.23 & 14.92 & 17.36 & 22.2 & 24.02 \\
\hline TOC (\%) & 3.64 & 2.32 & 2.55 & 2.83 & 2.88 & 1.91 & 2.23 & 2.66 & 2.76 \\
\hline TN (mg/kg) & 4.09 & 2.26 & 2.52 & 2.91 & 3.52 & 1.65 & 2.18 & 2.75 & 3.3 \\
\hline TP (mg/kg) & 2.95 & 1.63 & 1.82 & 2.1 & 2.54 & 1.19 & 1.57 & 1.99 & 2.39 \\
\hline
\end{tabular}

Table 8: Physicochemical Properties of Clay Soil after 84 Days Treatment. 


\begin{tabular}{|c|c|c|}
\hline Parameters & Before Pollution & After Pollution \\
\hline Density $(\mathrm{g} / \mathrm{cm} 3)$ & 0.43 & 1.06 \\
\hline E.C $(\mu \mathrm{S} / \mathrm{cm})$ & 20 & 26.9 \\
\hline $\mathrm{pH}$ & 5.93 & 5.5 \\
\hline $\mathrm{MC}(\%)$ & 2.3 & 42 \\
\hline TOC $(\%)$ & 0.96 & 3.77 \\
\hline $\mathrm{TN}(\mathrm{mg} / \mathrm{kg})$ & 3.72 & 7.18 \\
\hline $\mathrm{TP}(\mathrm{mg} / \mathrm{kg})$ & 2.33 & 5.52 \\
\hline
\end{tabular}

Table 9: Physicochemical Properties of Sandy Soil beforeand after Pollution.

\begin{tabular}{|c|c|c|c|c|c|c|c|c|c|}
\hline Parameters & Control & MW-500 & NW-500 & MA-500 & NA-500 & MW-600 & NW-600 & MA-600 & NA-600 \\
\hline Density $(\mathrm{g} / \mathrm{cm} 3)$ & 0.87 & 0.53 & 0.6 & 0.71 & 0.79 & 0.43 & 0.51 & 0.65 & 0.7 \\
\hline E.C $(\mu \mathrm{S} / \mathrm{cm})$ & 24.48 & 23.32 & 23.67 & 23.56 & 23.89 & 20.2 & 20.71 & 23.46 & 23.83 \\
\hline $\mathrm{pH}$ & 5.83 & 6.95 & 6.77 & 6.66 & 6.56 & 7.01 & 6.97 & 6.69 & 6.65 \\
\hline MC (\%) & 34.44 & 20.87 & 23.94 & 28.14 & 31.42 & 17.22 & 20.03 & 25.62 & 27.72 \\
\hline TOC (\%) & 2.94 & 1.87 & 2.06 & 2.29 & 2.33 & 1.55 & 1.8 & 2.15 & 2.23 \\
\hline TN (mg/kg) & 3.73 & 2.06 & 2.3 & 2.66 & 3.22 & 1.51 & 1.99 & 2.51 & 3.02 \\
\hline P $(\mathrm{mg} / \mathrm{kg})$ & 2.87 & 1.58 & 1.77 & 2.04 & 2.47 & 1.16 & 1.53 & 1.93 & 2.32 \\
\hline
\end{tabular}

Table 10: Physicochemical Properties of Sandy Soil after 84 Days Treatment.

Tables 3, 5, 7 and 9 shows the physicochemical properties of loamy,silt, clay, and sandy soilsbefore and after crude oil pollution, while Tables 4, 6. 8 and 10 show the physicochemical properties of loamy,silt, clay, andsandy after 84 days of treatment. The density, electrical conductivity (EC), moisture content (MC), total organic carbon (TOC), total nitrogen $(\mathrm{TN})$ and phosphorus $(\mathrm{P})$ in the soils were increased after crude oil was added, except forpH, which decreased slightly due to higher acid content in the pollutant than the soils. However, as shown in Tables 4, 6, 8 and 10, the density, electrical conductivity (EC), moisture content
(MC), total organic carbon (TOC), total nitrogen (TN) and phosphorus $(\mathrm{P})$ that was increased after the pollution of the soils, reduced appreciably after treated with moringer and neem extracted either by water or alcohol. The $\mathrm{pH}$ of the soils also increased from acidity to neutrality after the treatments.

Besides knowing which soil the treatments was most effective, it is also important to know which solution of moringa and neem roots extract performed better for the removal of TPH in the soils.

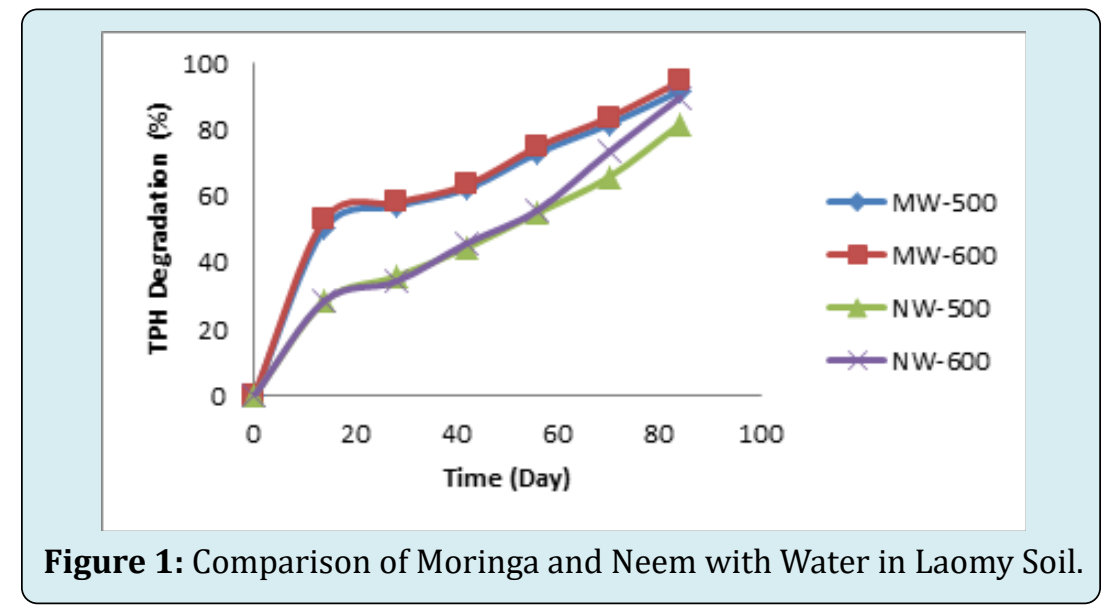




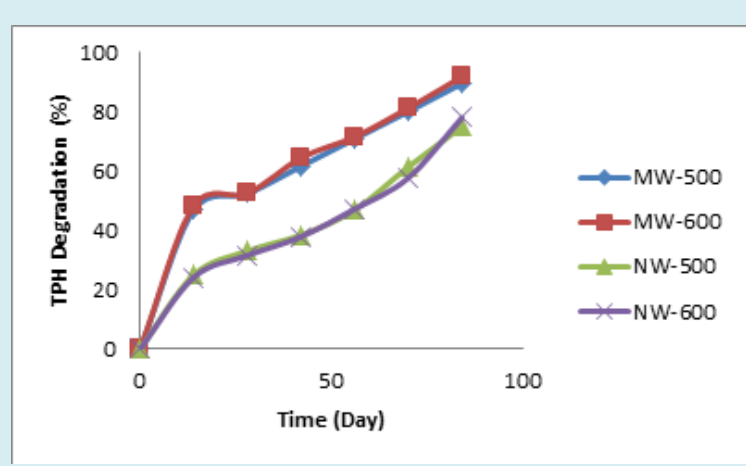

Figure 2: Comparison of Moringa and Neem with Water in Silt Soil.

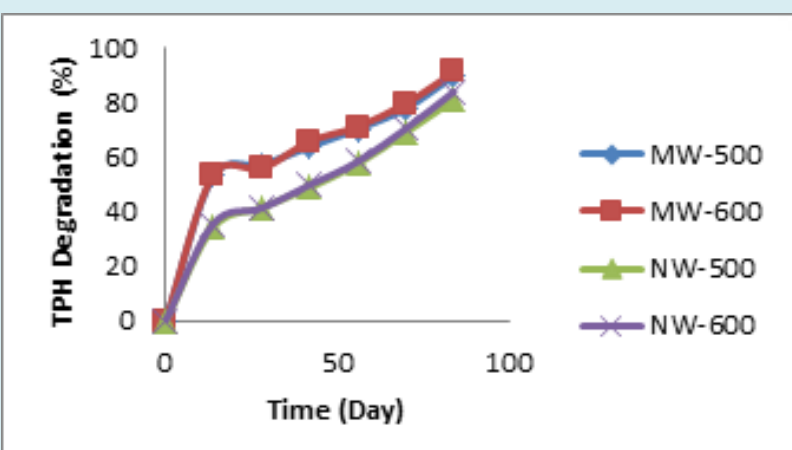

Figure 3: Comparison of Moring and Neem with Water in Clay Soil.

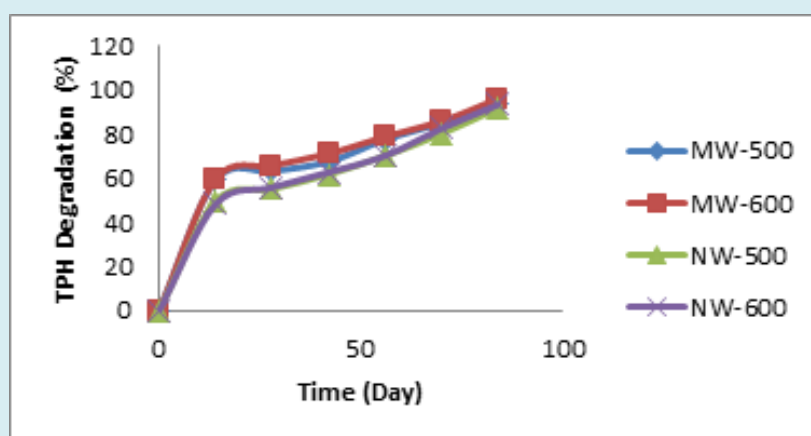

Figure 4: Comparison of Moringa and Neem with Water in Sandy Soil.

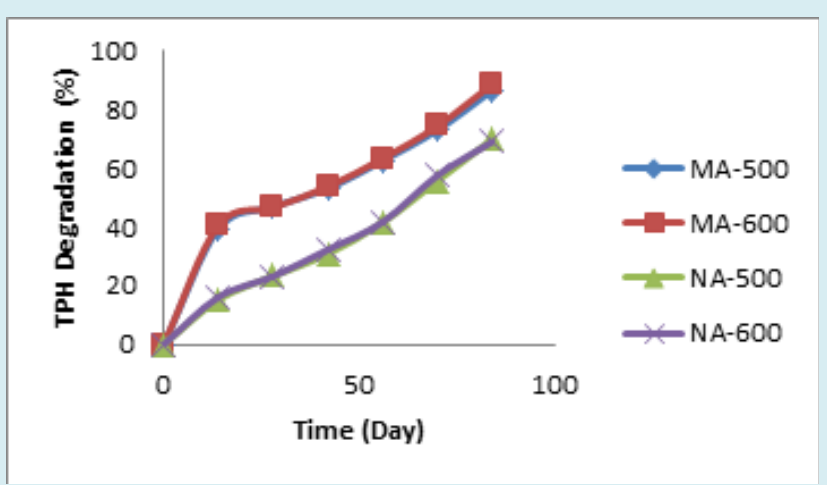

Figure 5: Comparison of Moringa and Neem with Alcohol in Laomy Soil. 


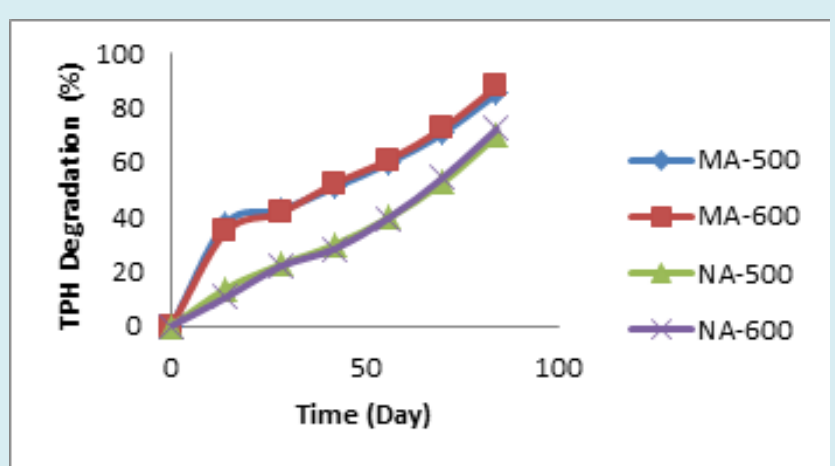

Figure 6: Comparison of Moringa and Neem with Alcohol in Silt Soil.

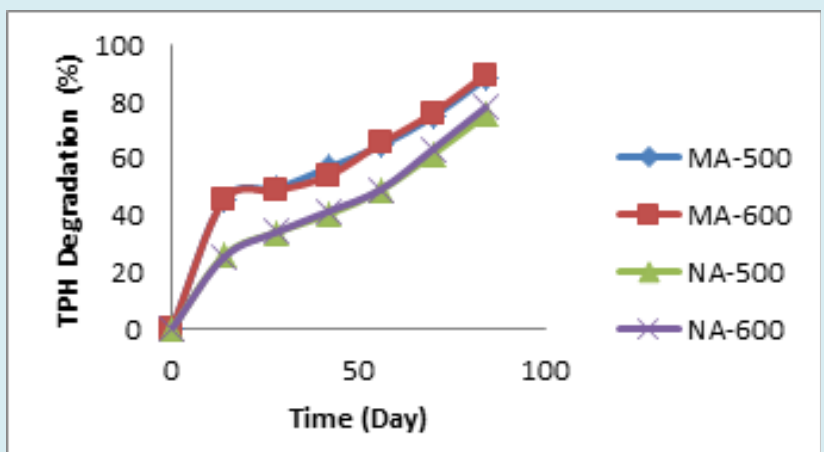

Figure 7: Comparison of Moringa and Neem with Alcohol in Clay Soil.

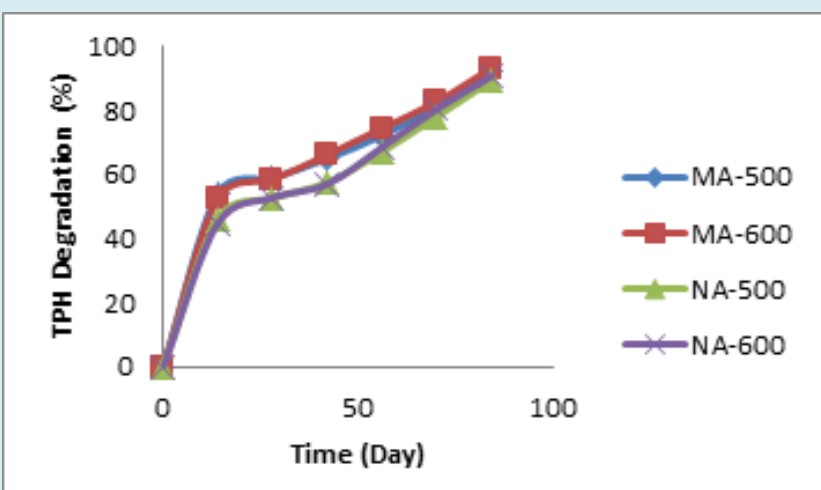

Figure 8: Comparison of Moringa and Neem with Alcohol in Sandy Soil.

Figures 1 to 4 show the comparison of percentage TPH degradation in loamy, silt, clay and sandy soils treated with moringa and neem in water solution. The percentage TPH degradation increased with time across the treatment formulation, but the rate of degradation differs for each treatment. Hence, the percentage TPH degradation inloamysoil are obtained as 91.85\%, 94.69\%, 81.75\% and $89.84 \%$ for MW-500, MW-600, NW-500, andNW-600 respectivelyat the end of the $84^{\text {th }}$ day.
For silt soil, as shown in Figure 2, the percentage TPH degradation increased with time across the treatment formulation. Hence, the percentage TPH degradation insilt soil are obtained as $89.61 \%, 91.90 \%, 75.07 \%$ and $78.07 \%$ for MW-500, MW-600, NW-500, andNW-600 respectively after 84 days.

Also,for clay soil as shown in Figure 3, the percentage TPH degradation increased with time across the treatments, 


\section{Petroleum \& Petrochemical Engineering Journal}

though, the rate of degradation differs for each treatment. Thus, the percentage TPH degradation in clay soil are obtained as $89.88 \%, 91.19 \%, 81.18 \%$ and $84.11 \%$ for MW500, MW-600, NW-500, and NW-600 respectively after 84 days.

Similarly, for sandy soil as shown in Figure 4, the percentage TPH degradation increased with time across the treatments, though, the rate of degradation differs for each treatment. Thus, the percentage TPH degradation insandy soil are obtained as $94.04 \%, 96.14 \%, 91.83 \%$ and $93.46 \%$ for MW-500, MW-600, NW-500, and NW-600 respectively after 84 days.

Similarly, Figures 5 to 8 show the percentage TPH degradation in loamy, silt, clay and sandy soils treated with moringa and neem in alcohol solution. Again, as shown in Figure 5, the percentage TPH degradation increased with time across the treatments, though, the rate of degradation differs. Hence, the percentage TPH degradation inloamysoil are obtained as $86.63 \%, 88.60 \%, 69.88 \%$ and $69.03 \%$ for MA-500, MA-600, NA-500, and NA-600 respectivelyafter 84 days.

For silt soil, as shown in Figure 6, the percentage TPH degradation also increased with time across the treatment formulation. Thus, the percentage TPH degradation in silt soil is $85.44 \%, 87.96 \%, 69.94 \%$ and $72.34 \%$ for MA-500, MA-600, NA-500, and NA-600 respectively after 84 days.

Also,for clay soil as shown in Figure 7, the percentage TPH degradation increased with time across the treatments. Thus, the percentage TPH degradation in clay soil are obtained as $88.44 \%, 89.67 \%, 75.51 \%$ and $78.14 \%$ for MA$500, \mathrm{MA}-600, \mathrm{NA}-500$, and NA-600 respectively after 84 days.

Finally, for sandy soil as shown in Figure 8, the percentage TPH degradation increased with time across the treatments. Thus, the percentage TPH degradation in sandy soilare obtained as $92.32 \%, 93.20 \%, 89.37 \%$ and $90.65 \%$ for MA$500, \mathrm{MA}-600, \mathrm{NA}-500$, and NA-600 respectively after 84 days.

\section{Conclusion}

The following conclusion was drawn from this study such as:

1. The performance of moringa and neem roots soaked in water and alcohol for bioremediation of crude oil polluted soils has been studied in this work and the results obtained revealed that remediation was rapid in bioreactors containing fermented moringa roots extract in water followed by neem roots extract in water.

2. However, remediation of crude oil and the growth of bacteria were least in alcohol than in water extracts, which can be traced to the volatile nature of alcohol to the microorganisms.

3. There was significant evidence of changes in physicochemical properties of the soils used for this study under the influence of the formulated treatments. The density, electrical conductivity (EC), moisture content (MC), total organic carbon (TOC), total nitrogen (TN) and phosphorus (P) in the soils increased after polluting the soils, except for $\mathrm{pH}$, which its case was the reverse. However, density, electrical conductivity (EC), moisture content (MC), total organic carbon (TOC), total nitrogen (TN) and phosphorus (P)decreasedremarkably with timeunder treatment, while the $\mathrm{pH}$ of the soils increased from acidity to neutrality after the treatments.

4. The total bacteria count increases across the soils with treatments up to the $56^{\text {th }}$ day of analysis, but declined gradually thereafter due to depletion of the nutrients in the soils. Sandy soil has the high growth of bacteria and least in silt soil for all the treatment formulations.

5. The degadation of TPH in the soils decreased across the soils, but higher in the soils with treatment. However, in each of the soil, the TPH removal was higher with treatment in water solution than in alcohol solution. Thus, the moringer and neem roots extracted in water performed better than in alcohol. Again, despite the high content of nutrient supplying agents recorded in clay soil, the best performance of the treatments was recorded in sandy soil.

6. Bioremediation of crude oil polluted soil can be effectively removed using several agro-based materials either as fine particles form or as originally obtained. This study has provided further knowledge on the applicability of agro materials like moringa and neem in different technique for bioremediation studies.

7. Thus, plant extract soaked in water or alcohol can be applied for effective treatment of soil polluted by crude oil. Also, different weights of soil with constant amount of treatment can affect the performance of formulated moringa and neem treatment for the removal of TPH from soil.

\section{References}

1. Ukpaka CP (2016) Development of Model for Bioremediation of Crude Oil using Moringa Extract. Chemistry International 2(1): 19-28.

2. Pawar RM (2015) The Effect of Soil pH on Bioremediation of Polycyclic Aromatic Hydrocarbons (PAHS). Journal of Bioremediation \& Biodegradation 6(3): 1-14.

3. Qin X, Tang J, Li D, Zhang Q (2012) Effect of Salinity on the Bioremediation of Petroleum Hydrocarbons in a Saline Alkaline Soil. Lett Appl Microbiol 55(3): 210-217. 


\section{Petroleum \& Petrochemical Engineering Journal}

4. Shao AJ, Wang SW, Chen X (2017) Experimental Determination of Coefficient of Soil Hydrodynamic Dispersion. Bulgarian Chemical Communications 8: 113118.

5. Balaji V, Arulazhagan P, Ebenezer P (2014) Enzymatic Bioremediation of Polyaromatic Hydrocarbons by Fungal Consortia Enriched from Petroleum Contaminated Soil and Oil Seeds. Journal of Environment and Biology 35(3): 521-529.

6. Udom BE, Nuga BO (2015) Biodegradation of Petroleum Hydrocarbons in a Tropical Ultisol Using Legume Plants and Organic Manure. Journal of Agricultural Science 7(4): 174-182.

7. Ukpaka CP, Nkakini SO (2017) Crude Oil Remediation using Matlab Integrated Agricultural Best Management Practice to Improved Soil Nutrients. Pet Petro Chem Eng J 1(1): 101-106.

8. Soloviev AV, Haus BK, McGauley MG, Dean CW, OrtizSuslow DG, et al. (2016) Surface Dynamics of Crude and Weathered Oil in the Presence of Dispersants: Laboratory Experiment and Numerical Simulation. Journal of Geophysical Research 121(5): 3502-3516.

9. Souza EC, Vessoni-Penna TC, Oliveira RPDS (2014) Biosurfactant-Enhanced Hydrocarbon Bioremediation: An Overview. International Biodeterioration \& Biodegradation Journal 89: 88-94.

10. Tharmer M, Al-Kubaisi AR, Zahraw Z, Abdullah HA, Hindy I, et al. (2013) Biodegradation of Kirkuk Light Crude Oil by Bacillus thuringiensis, Northern of Iraq. Natural Science 5(7): 865-873.

11. Ukpaka CP (2011) Biodegradation Model on Effect of Some Physicochemical Parameters on Aromatic Compounds in Fresh Water Medium, Journal of Bacteriology Research 3(3): 42-55.

12. Chaillan F, Châneau CH, Point V, Saliot A, Oudot J (2006) Factors Inhibiting Bioremediation of Soil Contaminated with Weathered Oils and Drill Cuttings. Environmental Pollution 144(1): 255-265.

13. Chibuike GU, Obiora SC (2014) Bioremediation of Hydrocarbon-Polluted Soils for Improved Crop Performance. International Journal of Environmental Sciences 4(5): 840-858.

14. Ukpaka CP (2017) Modelling the Methodology for Crude Oil Bioremediation Decision Tree for an Integrated Environmental Management System. J Chem Eng Process Technol 8(1): 1-5.
15. Bandura L, Woszuk A, Kolodynska D, Franus W (2017) Application of Mineral Sorbents for Removal of Petroleum Substances: A Review. Minerals 7(3): 1-25.

16. Bisht S, Pandey P, Bhargava B, Sharma S, Kumar V, et al. (2015) Bioremediation of Polyaromatic Hydrocarbons (PAHs) using Rhizosphere Technology. Braz J Microbiol 46(1): 7-21.

17. Bonomo R, Cennamo G, Purrello R, Santoro A, Zappala $R$ (2001) Comparison of three Fungal Laccases from Rigidoporus Lignosus and Pleurotus Ostreatus: Correlation between Conformation Changes and Catalytic Activity. Journal of Inorganic and Biochemical 83(1): 67-75.

18. Galdames A, Mendoza A, Orueta M, de Soto García IS, Sánchez M, et al. (2017) Development of New Remediation Technologies for Contaminated Soils Based on the Application of Zero-Valent Iron Nanoparticles and Bioremediation with Compost. Resource-Efficient Technologies 3(2): 166-176.

19. Haritash A, Kaushik C (2009) Biodegradation Aspects of Polycyclic Aromatic Hydrocarbons (PAHs): A Review. Journal of Hazardous Materials 169(1-3): 1-15.

20. Hesnawi RM, Adbeib MM (2013) Effect of Nutrient Source on Indigenous Biodegradation of Diesel Fuel Contaminated Soil. APCBEE Procedia 5: 557-561.

21. Heydataemeh MR, Aslani S, Doulati AF (2017) Loess Soil Nanoparticles as A Novel Adsorbent for Adsorption of Green Malachite Dye. J Chromatogr Sep Tech 8(3): 1-6.

22. Imanian H, Kolahdoozan M, Zarrati AR (2017) Vertical Dispersion in Oil Spill Fate and Transport Models. Journal of Hydrosciences and Environment 1(2): 21-33.

23. Jain PK, Gupta VK, Gaur RK, Lowry M, Jaroli DP, et al. (2011) Bioremediation of Petroleum Oil Contaminated Soil and Water. Research Journal of Environmental Toxicology 5(1): 1-26.

24. Khalilova HK (2015) The Impact of Oil Contamination on Soil Ecosystem. Journal of Biological and Chemical Research 3: 133-139.

25. Khodadadi A, Ganjidoust H, Seyed Razavi SNS (2012) Treatment of Crude-Oil Contaminated Soil using Biosurfactants. Journal of Petroleum and Gas Engineering 3(6): 92-98. 